\title{
ANALIZA PRZEBIEGU EGZEKUCJI Z INSTRUMENTÓW FINANSO- WYCH ZAPISANYCH NA RACHUNKU PAPIERÓW WARTOŚCIOWYCH
}

\author{
ANALYSIS OF THE EXECUTION OF FINANCIAL INSTRUMENTS \\ RECORDED ON THE SECURITIES ACCOUNT
}

\begin{abstract}
Streszczenie: Egzekucja z instrumentów zapisanych na rachunku papierów wartościowych jest nową instytucją przewidzianą przez ustawodawcę. Ten sposób egzekucji jest niedoskonały $i$ posiada wiele wad. Ten sposób egzekucji jest również skomplikowany i często rozległy $\mathrm{w}$ czasie. Ze względu na ekonomikę postępowania egzekucyjnego, a także chęci wierzyciela na szybkie odzyskanie należności zasądzonych tytułem wykonawczym wierzyciele składają wnioski o przeprowadzenie egzekucji z innego majątku dłużników. Z praktycznego punktu widzenia często nie jest to skuteczny sposób egzekucji z racji braku znaczącej wartości wskazanych przedmiotów. Celem artykułu jest przedstawienie przebiegu egzekucji z instrumentów finansowych zapisanych na rachunku papierów wartościowych.
\end{abstract}

Słowa kluczowe: komornik, egzekucja należności, wierzyciel, dłużnik, postępowanie cywilne

Received: 07.2018

\begin{abstract}
Enforcement from instruments entered into a securities account is a new institution provided for by the legislator. This method of execution is imperfect and has many disadvantages. This method of execution is also complicated and often extensive in time. Due to the economics of the enforcement proceedings, as well as the willingness of the creditor to quickly recover the claims awarded in the enforcement title, the creditors submit applications for enforcement from another debtor's property. From a practical point of view, it is often not an effective way of execution due to the lack of significant value of the items indicated. The purpose of the article is to present the course of execution from financial instruments recorded on the securities account.
\end{abstract}

Key words: bailiff, debt collection, creditor, debtor, civil proceedings.

Accepted: 12.2018

\footnotetext{
* asesor komorniczy w Kancelarii Komornika Sądowego przy Sądzie Rejonowym w Olsztynie Michała Krokowskiego
} 


\section{Wstęp}

Egzekucja z instrumentów finansowych zapisanych na rachunku papierów wartościowych jest dość nową instytucją, która pojawiła się w kpc. Została unormowana w odrębnym dziale na podstawie nowelizacji kpc z 2004 roku.

Ten rodzaj egzekucji zaczął się rozwijać po przemianach ustrojowych w 1989 roku. W tym czasie znacznie wzrósł obrót papierami wartościowymi o charakterze materialnym. W szczególności akcjami i obligacjami, które wraz z udziałami w spółkach z ograniczoną odpowiedzialnością stały się atrakcyjnym przedmiotem zaspokojenia roszczeń wierzycieli w egzekucji sądowej. Jednocześnie z powstaniem rynku kapitałowego, a także Giełdy Papierów Wartościowych S.A. w Warszawie pojawiła się potrzeba regulacji prawnej dla tego rodzaju egzekucji. Wszelkie rozwiązania prawne dotyczące egzekucji z papierów wartościowych były niedoskonałe. Dopiero nowelizacja kpc w 2004 roku [Ustawa z dnia 17 listopada 1964] spowodowała rozwój oraz rozwianie większości wątpliwości związanych z egzekucją z instrumentów finansowych zapisanych na rachunku papierów wartościowych.

Celem niniejszego artykułu jest przybliżenie funkcjonowania systemu egzekucji z instrumentów finansowych zapisanych na rachunku papierów wartościowych. Jest to proces niezwykle skomplikowany i poddawany modyfikacjom ze względu na ciągle rozwijający się rynek papierów wartościowych. W artykule dokonano również wyjaśnienia pojęć związanych z instrumentami finansowymi, a także wskazano jakie instrumenty finansowe są zaliczane do papierów wartościowych.

Rozpoczynając rozważania na temat tego rodzaju egzekucji należy wyjaśnić, czym jest instrument finansowy. Definicję tego pojęcia można odnaleźć w art. 2 Ustawy o obrocie instrumentami finansowymi (Dz.U. z 2016 r. poz. 1636 ze zm.). Przepis ten dzieli instrumenty finansowe na papiery wartościowe oraz instrumenty finansowe niebędące papierami wartościowymi [Ustawa z dnia 29 lipca 2005]. Papierami wartościowymi są zatem zgodnie $z$ art. 3 wspomnianej ustawy akcje, prawa poboru, prawa do akcji, warranty subskrypcyjne, kwity depozytowe, obligacje, listy zastawne, certyfikaty inwestycyjne i inne zbywalne papiery wartościowe w tym inkorporujące prawa majątkowe odpowiadające prawom wynikającym z akcji lub z zaciągnięcia 
długu, wyemitowane na podstawie właściwych przepisów prawa polskiego lub obcego. Są to również inne zbywalne prawa majątkowe, które powstają w wyniku emisji, inkorporujące uprawnienie do nabycia lub objęcia papierów wartościowych wskazanych wyżej lub wykonywane poprzez dokonanie rozliczenia pieniężnego.

\section{Wyjaśnienie pojęć instrumentów finansowych będących i niebędących papie- rami wartościowymi}

Do instrumentów niebędących papierami wartościowymi zaliczane są tytuły uczestnictwa w instytucjach wspólnego inwestowania, instrumenty rynku pieniężnego, opcje kontrakty terminowe, swapy, umowy forward na stopę procentową, inne instrumenty pochodne których instrumentem bazowym jest papier wartościowy, waluta, stopa procentowa, wskaźnik rentowności lub inny instrument pochodny, indeks lub wskaźnik finansowy, bądź też których instrumentem bazowym jest towar, który jest rozliczany pieniężnie lub przez dostawę. Instrumentami finansowymi niebędącymi jednocześnie papierami wartościowymi mogą być również niedopuszczone do obrotu na rynku regulowanym ani w alternatywnym systemie obrotu akcje, kontrakty terminowe, swapy, umowy forward na stopę procentową, inne instrumenty pochodne, których instrumentem bazowym jest towar, które mogą być wykonane przez dostawę, ale nie są przeznaczone do celów handlowych i wykazują właściwości innych pochodnych instrumentów finansowych. Ponadto są to instrumenty pochodne dotyczące przenoszenia ryzyka kredytowego oraz kontrakty na różnicę.

Na podstawie powyższego można stwierdzić, że przedmiotem tego rodzaju egzekucji są instrumenty finansowe zapisane na rachunku papierów wartościowych tj. instrumenty zdematerializowane, które stanowią przedmiot obrotu na rynku regulowanym. Na podstawie wskazanych przepisów przedmiotem egzekucji mogą być również instrumenty finansowe zapisane na innym rachunku. To znaczy takie, które nie podlegają dematerializacji systemowej, czy też autonomicznej (w odniesieniu do papierów wartościowych) [Jankowski (red.), 2015].

Zgodnie z przyjętymi rozwiązaniami przez ustawodawcę egzekucja nie jest kierowana do poszczególnych praw majątkowych czy wierzytelności 
włączonych w instrumencie finansowym. Przedmiotem postępowania jest instrument finansowy traktowany jako ogół praw, które stanowią samodzielny przedmiot obrotu [Szumański (red.), 2016].

\section{Pojęcie instytucji poddłużnika i jego znaczenie w postępowaniu egzekucyjnym}

W egzekucji z papierów wartościowych istotną rolę pełni instytucja poddłużnika. Dotychczas wskazano dwa stanowiska wskazujące jaki podmiot pełni rolę poddłużnika. Konstrukcja pierwszego ze stanowisk opiera się na tym, że emitent zdematerializowanego papieru wartościowego nie pełni takiej samej roli jak w egzekucji akcji materialnych. Oznacza to, że osoba, która jest emitentem i spełnia swoje świadczenie osobie uprawnionej jest zawiadamiana o zajęciu. Jednocześnie emitent jest wzywany aby poinformował o prowadzonej egzekucji oraz nie spełniał świadczenia do rąk dłużnika, lecz złożył je komornikowi lub też na rachunek depozytowy Ministra Finansów (dawniej depozyt sądowy). W rezultacie należy uznać, że wezwanie komornika związane z zajęciem zdematerializowanych papierów wartościowych kierowane jest wyłącznie do podmiotu prowadzącego rachunek papierów wartościowych dłużnika [Rośniak-Rutkowska, 2004].

Drugie $z$ omawianych stanowisk w kwestii ujmowania poddłużnika także zauważa dość znaczną rolę podmiotu prowadzącego rachunek papierów wartościowych w omawianym sposobie egzekucji. Zakłada się, że przedmiotem egzekucji są prawa majątkowe względne, inkorporowane w zdematerializowanym papierze wartościowym [Cieślak, 2003]. Ujęcie w ten sposób przedmiotu zajęcia egzekucyjnego prowadzi do uznania, że obowiązkiem wobec dłużnika mogą być obciążone dwa podmioty tj. emitent a także prowadzący rachunek papierów wartościowych. Zaproponowano dwa sposoby ustalenia osoby poddłużnika. Pierwszy ze sposobów oznacza, że w stosunku do spółki dochodzi do zajęcia akcji jako ogółu praw i obowiązków. W stosunku do prowadzącego rachunek zdematerializowanych papierów wartościowych możemy mówić o zajęciu określonych konkretnych praw czyli wierzytelności pieniężnej o wypłatę środków zgromadzonych na rachunku pieniężnym. Drugi zaś oznacza, że pod pojęciem poddłużnika występują dwa podmioty. Są to emitent oraz podmiot prowadzący rachunek dłużnika [Cieślak, 2003]. 
Na podstawie powyższych rozważań można podjąć próbę zdefiniowania instytucji poddłużnika. Poddłużnikiem będzie osoba wezwana przez komornika i tym samym zobowiązana przez niego do dokonania określonych czynności w toku egzekucji. Są to obowiązki tego samego rodzaju, które nakładane są na trzeciodłużnika (czyli osoby zobowiązanej do przekazywania należności przysługującej dłużnikowi) w toku egzekucji z wierzytelności czy też praw majątkowych. W zaistniałym przypadku mamy do czynienia z sytuacją, gdzie obowiązki o swoistym charakterze procesowym, odnoszą się do prawa lub wierzytelności, które nie są przedmiotem zajęcia. Poddłużnik nie będzie zobowiązany wobec dłużnika egzekwowanego z mocy zajętego prawa. Zobowiązanie poddłużnika wynika z odrębnego stosunku prawnego tj. umowy o prowadzenie rachunku papierów wartościowych lub innego rachunku, umowy o prowadzenie rachunku pieniężnego czy też umowy o wykonanie zleceń nabycia lub zbycia instrumentów finansowych. Poddłużnik, jest zobowiązany do określonych czynności w postępowaniu egzekucyjnym z mocy zajęcia, czyli stosunku cywilnoprocesowego [Jankowskiego (red.), 2015].

Warto wskazać, że w egzekucji ze zdematerializowanych instrumentów finansowych, emitenta tych instrumentów nie uznaje się za poddłużnika. Takie ujęcie emitenta spowodowane jest dwoma warunkami. Przede wszystkim ustawodawca nie nakłada na emitenta obowiązków w postępowaniu egzekucyjnym. Wezwanie do spełnienia świadczenia, wskazane $w$ art. $911^{5}$ kpc nie będzie miało zastosowania w omawianym rodzaju egzekucji. Wyłączałoby to obowiązujący, zgodnie z przepisami ustawy o obrocie instrumentami finansowymi, mechanizm prawny realizacji pośredniej praw majątkowych inkorporowanych $w$ zdematerializowanych instrumentach finansowych. Wynika z tego, że wierzyciel nie może żądać od emitenta, aby ten spełnił świadczenie do jego rąk, bądź też komornikowi [Uliasz, Warszawa 2008].

Możliwe jest również występowanie po stronie poddłużnika więcej niż jednego podmiotu. Sytuacja taka będzie miała miejsce $w$ momencie gdy w egzekucja zostanie skierowana do instrumentów finansowych zapisanych na rachunku papierów wartościowych prowadzonych przez bank powierniczy. Bank powierniczy nie będzie prowadził rachunku pieniężnego na rzecz dłużnika ani też nie będzie świadczył usług dotyczących wykonywania zleceń 
nabycia lub zbycia instrumentów finansowych. Łatwo się domyślić zatem, że dłużnika łączą umowy z firmą inwestycyjną. W celu realizacji obowiązku niezbędna jest więc kooperacja w roli poddłużnika banku powierniczego oraz firmy inwestycyjnej [Szczurek (red.), 2013]

\section{Tryb postępowania w egzekucji z instrumentów finansowych zapisanych na}

\section{rachunku papierów wartościowych}

Wszczęcie egzekucji z instrumentów finansowych zapisanych na rachunku papierów wartościowych następuje poprzez złożenie wniosku przez wierzyciela. I tak w egzekucji z instrumentów finansowych ważną kwestią jest sposób oznaczenia we wniosku przez wierzyciela sposobu egzekucji. Sprowadza się to do wskazania przedmiotu egzekucji. Przedmiot winien we wniosku być dokładnie oznaczony i zindywidualizowany. Wniosek taki musi wskazywać, że przedmiotem egzekucji będą objęte wszystkie instrumenty finansowe zapisane na rachunku papierów wartościowych lub innych rachunków w chwili zajęcia. Kolejną istotną częścią wniosku będzie wskazanie numeru rachunku, na którym są zapisane instrumenty finansowe, a także dokładnie oznaczenie podmiotu, który ten rachunek prowadzi. Ze względu na to, że przedmiotem egzekucji są również środki pieniężne, to także one wymagają wskazania we wniosku. W doktrynie jednakże można spotkać stanowiska, które negują wskazywanie we wniosku instrumentów finansowych. Jednym $z$ argumentów, zasługujących na uwagę jest to, że wierzyciel nie musi wcale znać $w$ chwili zajęcia stanu rachunku, na którym zapisane są instrumenty finansowe dłużnika. Taką informację uzyska w dalszym etapie egzekucji od poddłużnika lub komornika [Piasecki, Marciniak (red.), Warszawa 2012].

Przedmiotem zajęcia w niniejszym rodzaju egzekucji będzie wierzytelność lub prawo majątkowe, których podstawą jest stosunek materialnoprawny między dłużnikiem i wierzycielem w znaczeniu materialnym. Na przedmiot stosunku cywilnoprocesowego, który powstaje z mocy zajęcia składa się owa wierzytelność lub prawo. Podmiotami tego rodzaju stosunku są strony stosunku materialnoprawnego, natomiast ich obowiązki dotyczące stosunku zobowiązaniowego w znacznej mierze. Poza przedmiotem dwojakiego rodzaju, nietypowe dla egzekucji z instrumentów finansowych jest to, że wszelkie czynności dłużnika egzekwowanego i poddłużnika składające się 
na zajęcie są właściwe dla stosunku umownego pomiędzy wymienionymi podmiotami.

Opisując ten rodzaj egzekucji należy zwrócić uwagę na kwestie czysto techniczne. Zajęcie instrumentów finansowych składa się więc z czynności wobec dłużnika oraz poddłużnika. Komornik zawiadamia dłużnika, że nie wolno mu odbierać żadnego świadczenia, jak również rozporządzać zajętymi instrumentami finansowymi czy wartościami zebranymi na rachunku. Wyjątkiem będą zlecenie sprzedaży instrumentów finansowych dłużnika na wezwanie podmiotu prowadzącego działalność maklerską, w którym dłużnik ma rachunek. Jednocześnie poddłużnik jest wzywany, aby nie dokonywał dyspozycji dłużnika ani też nie wypłacał dłużnikowi pieniędzy ulokowanych na jego rachunku, lecz zajęte sumy pieniężne do wysokości egzekwowane należności wydał komornikowi czy też złożył na rachunek depozytowy Ministerstwa Finansów (dawniej rachunek depozytowy sądu rejonowego) [RośniakMarczuk, 2011].

Zakaz odbierania świadczeń przez dłużnika oraz zakaz rozporządzania zajętymi instrumentami finansowymi wiąże się z pewnymi niejasnościami. Zakazem odbierania świadczeń nie są objęte te, które pochodzą od poddłużnika. Jego zobowiązania wobec dłużnika nie mają charakteru majątkowego. Przedmiotem będzie więc świadczenie przypadające z tytułu realizacji praw majątkowych włączonych w zajmowanych instrumentach finansowych. Zakaz rozporządzania zajętymi instrumentami finansowymi oznacza, że dłużnikowi nie wolno wystawiać zleceń sprzedaży zajętych instrumentów ani dokonywać ich sprzedaży na podstawie indywidualnej umowy z nabywcą poza rynkiem. Czynność przeksięgowania nie ma charakteru rozporządzającego, dlatego też skutek tej czynności jest tożsamy ze zbyciem. Przeksięgowane dokumenty zostają zapisane na innym rachunku niż oznaczony we wniosku egzekucyjnym. Dokonanie przeksięgowania powoduje negatywny skutek dla postępowania egzekucyjnego w postaci usunięcia przedmiotu zajęcia. Ze względu na to, że egzekucja jest skierowana do instrumentów zapisanych na konkretnym rachunku wskazanym we wniosku egzekucyjnym, przeprowadzenie egzekucji z instrumentów finansowych zapisanych na innym rachunku wymaga dokonania nowego zajęcia [Rośniak, 2007].

W sprawach czysto technicznych warto zwrócić uwagę na obowiązki jakie są nakładane na poddłużnika. Nie może on wykonywać dyspozycji zło- 
żonych przez dłużnika. Jednakże, zakaz ten nie dotyczy wszystkich dyspozycji, do składania których dłużnik jest uprawniony na podstawie umów łączących go z poddłużnikiem. Wniosek o całkowitym zakazie wykonywania dyspozycji przez poddłużnika byłby zasadny w momencie zajęcia wierzytelności wynikających z umów wiążących dłużnika i poddłużnika. Zakazem są zatem objęte takie dyspozycje, których wykonanie przez poddłużnika mogłoby uniemożliwić zaspokojenie wierzyciela egzekwującego. Takimi dyspozycjami są:

1. Dyspozycje dotyczące rozporządzanie środkami pieniężnymi zgromadzonymi na rachunku pieniężnym dłużnika.

2. Dyspozycje zbycia zajętych instrumentów finansowych w drodze zlecenia lub w drodze indywidualne umowy sprzedaży poza rynkiem regulowanym.

3. Dyspozycje przeksięgowania zajętych instrumentów finansowych na inny rachunek papierów wartościowych należący do dłużnika.

Należy również wskazać, że poddłużnik ma obowiązek do złożenia oświadczenia komornikowi. Oświadczenie musi zawierać informację, o roszczenia innych osób do zajętego prawa. Ma to na celu ochronę praw innych osób. Ponadto oświadczenie, o ile takie występuje, powinno zawierać informacje o przeszkodach, o ile takie zachodzą. W szczególności trzeba poinformować o braku środków pieniężnych w egzekwowanej wysokości, czy zajęcie dokonane jest już na rzecz innego wierzyciela oraz czy zachodzi zbieg egzekucji administracyjnej lub sądowej bądź sądowo administracyjnej [Rośniak, 2007].

Poddłużnik w egzekucji z instrumentów finansowych zapisanych na rachunku papierów wartościowych winien być zobowiązany do ustanowienia blokady zajętych instrumentów finansowych. Jest to jeden z koniecznych elementów zajęcia, a także warunkuje skuteczność prowadzonej egzekucji. Blokada taka uniemożliwia dokonanie dyspozycji dłużnika celem rozporządzenia zajętymi instrumentami finansowymi [Romańska, 2009].

Kolejnym etapem egzekucji jest sprzedaż zajętych instrumentów finansowych. Ustawodawca przewidział tylko jeden sposób sprzedaży egzekucyjnej. Chodzi tutaj o sprzedaż na zlecenie wystawione firmie inwestycyjnej. Dłużnik, wierzyciel oraz kurator mogą sprzedać instrumenty finansowe jedynie w drodze zlecenia. Należy zwrócić uwagę, że zostały pominięte inne sposoby sprzedaży egzekucyjnej instrumentów finansowych zapisanych na ra- 
chunku papierów wartościowych, które są dopuszczalne na podstawie przepisów prawa materialnego. Niemożliwe jest zatem, sprzedaż instrumentów finansowych bez zlecenia, czyli na podstawie indywidualnej umowy sprzedaży zawieranej poza rynkiem zlecenia, która nie pozostaje w związku z realizacją umowy o wykonanie zleceń. Instrumentów finansowych nie można również sprzedać na podstawie publicznej licytacji. Niemożliwe jest również przejęcie instrumentów finansowych przez wierzyciela w miejsce zapłaty jak to zostało przewidziane w egzekucji z ruchomości [Uliasz, 2008].

\section{Podsumowanie}

Egzekucja z instrumentów finansowych zapisanych na rachunku papierów wartościowych jest procesem skomplikowanym. Ten rodzaj egzekucji w kancelariach komorniczych prowadzony jest dość rzadko. Wierzyciele, składając wniosek egzekucyjny do komornika, wolą zawnioskować o egzekucję z innego majątku. Odzyskiwanie należności poprzez egzekucję z instrumentów finansowych zapisanych na rachunku papierów wartościowych często jest nieskuteczny. W związku z tym wierzyciele, będą wnosić o egzekucję z majątku, którego sprzedaż w pełnej wysokości lub w większej części zaspokoi roszczenie objęte tytułem wykonawczym. Wskazany rodzaj egzekucji ulega ciągłym modyfikacjom, ze względu na rozwój legislacji dotyczącej papierów wartościowych.

\section{Bibliografia}

Chłopecki A. [w:] System prawa prywatnego, t. 18, pod red. A. Szumańskiego, Warszawa 2016

Cieślak S., Egzekucja przeciwko spółce handlowej oraz z akcji i udziałów w tej spółce, PPE 2003

Dumnicka O. [w:] Postępowanie zabezpieczające i egzekucyjne. Komentarz do części drugiej i trzeciej Kodeksu postępowania cywilnego, pod red. M. Romańskiej, Warszawa 2009

Julke G. [w:] Kodeks postępowania cywilnego. Postępowanie zabezpieczające i egzekucyjne. Komentarz, pod red. Z. Szczurka, Sopot 2013 
Rośniak M., Zawiadomienie dłużnika o zajęciu instrumentów finansowych zapisanych na jego rachunku oraz brak obowiązku powiadamiania o tym fakcie spółki, PPE 2007 Rośniak-Marczuk M., Egzekucja sądowa z instrumentów finansowych, Warszawa 2011

Rośniak-Marczuk M. [w:] Kodeks postępowania cywilnego, pod red. J Jankowskiego, Warszawa

2015

Rośniak-Marczuk M., Egzekucja sądowa z instrumentów finansowych, Warszawa 2011

Rośniak-Rutkowska M., Egzekucja z akcji, PPE, nr 4, Sopot 2004

Sychowicz M. [w:] Kodeks postępowania cywilnego. Tom III. Postępowanie nieprocesowe, w razie zginięcia i zniszczenia akt, zabezpieczające i egzekucyjne. Komentarz do artykułów 506-1088, pod red. K. Piaseckiego, A. Marciniaka, Warszawa 2012 Uliasz M., Kodeks postępowania cywilnego. Komentarz, Warszawa 2008 Ustawa z dnia 29.07.2005 o Obrocie Instrumentami Finansowymi (Dz.U. z 2016 poz. 1636 ze zm.) 